\title{
From 'Imitation' to 'Indigenization': A Study of Shakespeare Performances in Colonial Calcutta
}

\author{
Vikram Singh Thakur \\ Dr. B.R. Ambedkar University \\ vikram@aud.ac.in
}

\begin{abstract}
The plays of William Shakespeare have been performed all over the globe. This is particularly true of the erstwhile colonies of Britain and India is no exception. Along with other English playwrights, Shakespeare's plays began to be performed in India during the eighteenth century by British officials for their entertainment. Educated Indians took these performances as a model to develop 'modern' Indian theatre. The present essay engages with Shakespeare production in colonial Calcutta, starting with Shakespeare performances in English before moving on to consider the later process of 'indigenizing' Shakespeare. The essay also proposes that Shakespeare production in Calcutta after the 1850s when Shakespeare's plays moved out of the confines of schools and colleges has been governed by its own aesthetics.
\end{abstract}

Shakespeare has been in the repertoire of modern Indian theatre for at least two centuries. Shakespeare production in India has, however, never been uniform. Shakespeare's plays were performed, at least initially, by English-educated Indians in 'imitation' of those staged by British officials in India during the eighteenth and nineteenth centuries. However, there was a gradual and noticeable assimilation of Shakespeare's plays into indigenous theatrical activities. An illustrative example is the Shakespeare performances in colonial Calcutta (now Kolkatta). The present essay seeks to study Shakespeare performances in colonial Calcutta and tries to identify the shift from 'imitation' to 'indigenization'. The essay is divided into three sections. Section 1 deals with Shakespeare performances staged by British officials in India in the 
eighteenth and nineteenth centuries. Section 2 discusses the rise of English education in India, which provided school and college students with a formal introduction to Shakespeare's plays; these students went on to perform them in 'imitation' of the English theatres in Calcutta. Section 3 traces the transformation from the 'imitative' phase to that of 'indigenization', whereby Shakespeare's plays were translated, adapted and sometimes appropriated into a more familiar Bengali context for Calcutta audiences, which helped to popularize Shakespeare among the masses of the city.

\section{Performing Shakespeare in the English theatres of colonial Calcutta}

Shakespeare productions in India date back to mid-eighteenth century, when British officers in India staged the Bard's plays along with those of other eminent English playwrights for entertainment. The sources of entertainment were limited to British officials, and so English theatre was 'imported' to Calcutta. Many playhouses came into existence as a consequence. Nandi Bhatia notes that theatres formed an important part of British social life in India as early as 1757 (2004: 12). Poonam Trivedi and Jyotsna Singh note that the earliest modern theatre to be established in India was The Calcutta Theatre (1775) (2005: 13 \& 1996: 121). However, Sushil Kumar Mukherjee, a scholar of Bengali theatre, states that much before The Calcutta Theatre, the first English theatre to be set up in Calcutta was The Playhouse in 1753 which received help from David Garrick, one of the most celebrated actors of London (1982: 2). The Playhouse shut down soon after Nawab Siraj-ud-Daula's attack on Calcutta in 1756. It was 19 years later in 1775 during the Governer Generalship of Warren Hastings (1772-1785) that The New Playhouse or The Calcutta Theatre was built. The Calcutta Theatre ran for 33 years until it was closed down due to financial strain. David Garrick, who had earlier helped to set up the Playhouse, supplied a number of painted scenes from London and an artist named Bernard Messink. Mukherjee quotes from a letter of 26 March 1781 (by Mrs. Eliza Fay) that this playhouse was well-equipped and "very neatly fitted up and the scenery and decoration quite equal to what could be expected here" (cited in Mukherjee 1982: 2). The Calcutta Theatre staged plays of Shakespeare, Massinger, Congreve, Sheridan and others. Trivedi notes that among various plays staged here, some eight plays were by Shakespeare, which were performed more than once (2005: 14). The Calcutta Theatre was known for its performances and got special mention in the reviews of the newspapers. For example, the following is a review of The Merchant of Venice published in Selections from Calcutta Gazettes (29):

Thtrsday, OCTOBER $21 \mathrm{sT}, 1784$.

Calcutta.

On Monday evening the Comedy of the "Merchant of Venice" was performed here to a very full theatre. Shylock never appeared to greater advantage, and the other characters were, in general, well supported. 
On 11 November 1784, a production of Hamlet was advertised as follows (Selections from Calcutta Gazettes 30):

\section{Thursday, Novesber 11th, 1784 .}

Calculta.

We hear the Tragedy of "Hamlet" will be performed in the course of next week; but the managers have thought proper to omit the farce of the "Mock Doctor." For the better accommodation of the Ladies and Gentlemen of the Settlement, the Gallery is to be converted into Boxes.

In the meantime several other playhouses were established, like Mrs. Bristow's Private Theatre (1789-90), Wheeler Place Theatre (1797-98), Atheneum Theatre (1812-14), The Chowringhee Theatre (1813-39), Dum Dum Theatre (1817-24), Baitaconah Theatre (1824) and Sans Souci Theatre (1839-49). The number of such English playhouses shows the growing status of theatre in the social life of the British. Besides the repertoire of their own local actors, the playhouses also invited actors from London. Mrs. Atkinson, for example, came from Drury Lane Theatre and Mrs. Chester from London's Royal Theatre; James and Mrs. Barry, Mrs. Deacle, Miss Cowley and James Vining came from Covent Garden and Drury Lane Theatres. It is therefore clear that Shakespeare was one of the major dramatists to be produced in India, especially in cities like Calcutta and Bombay in colonial times. Singh argues that Shakespeare was readily imported to India since:

the productions of Shakespeare's works enjoyed great popularity in Britain from the late eighteenth to the end of the nineteenth centuries. And by the mid-Victorian period, the grand-scale pictorial realism of the London productions, combined with the trend of canonizing individual characters, had left a strong impression on the popular imagination. Shakespeare's characters and plots had become both commonplace and a source of inspiration for artists and writers. Thus, the Victorian colonists in India, while apishly promoting Shakespeare's works in colonial Calcutta, were, in effect, reproducing the metropolitan culture as a part of the "civilizing mission" of the British Raj. ( Singh 1996: 122)

Among the above-mentioned theatres, Chowringhee (established in 1813) and Sans Souci were specially known for their Shakespeare performances such as Henry IV, Richard III, The Merry Wives of Windsor, The Merchant of Venice and Othello. Chowringhee could boast of the finest talents of its times like D. L. Richardson, Horace Haymen, Esther Leach, Henry Meredith Parker and J. H. Stokler, famous for enacting characters like Iago, Cassius and Falstaff. Chowringhee Theatre continued until May 1839 when a fire tragically destroyed it completely. 


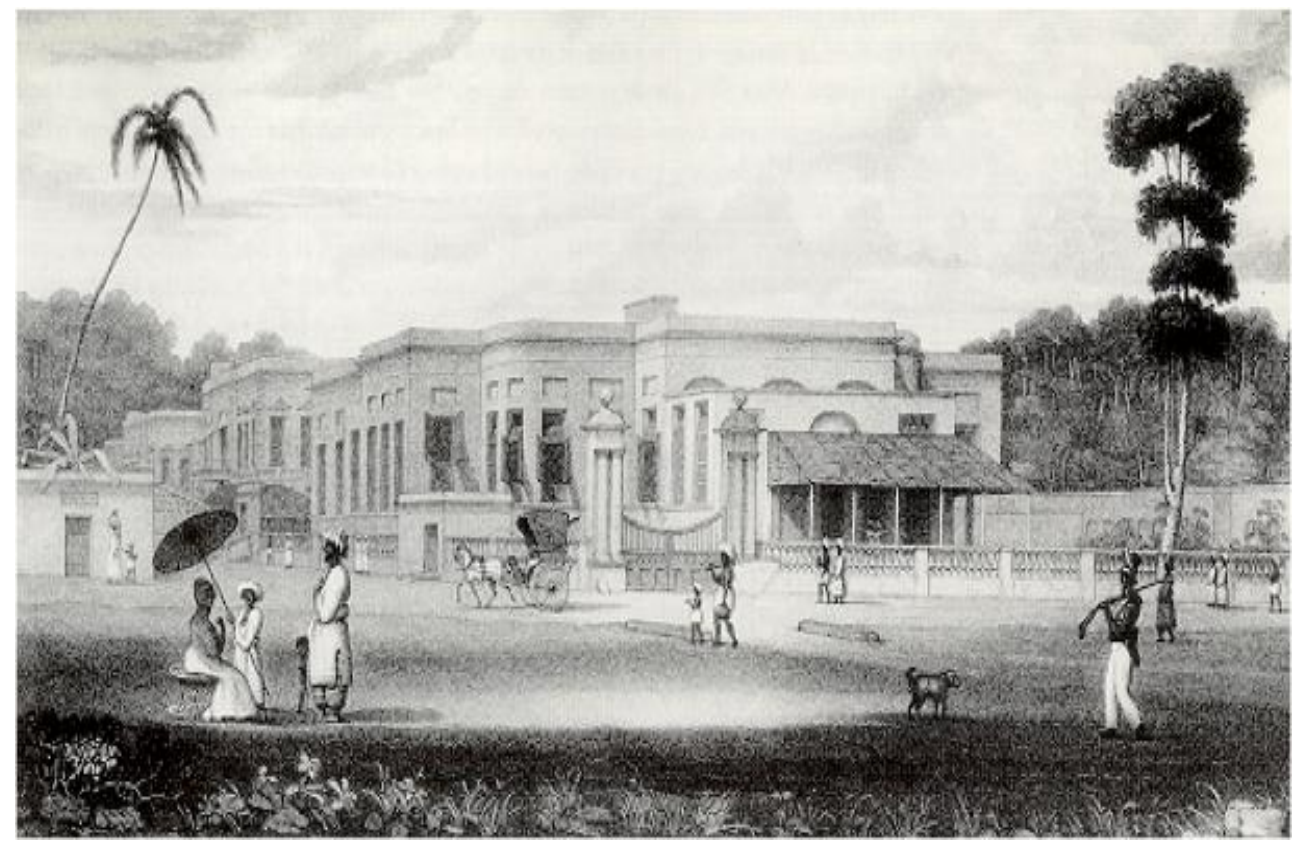

The Chowringhee Theatre, Calcutta (Source: Mukherjee, 1982: 545).

In August of the same year when Chowringhee was gutted, Mrs. Leach, previously associated with Chowringhee, opened Sans Souci in Waterloo Street. Sans Souci continued to stage plays here for a year while a bigger theatre was being built in Park Street by public subscription. Dwarkanath Tagore and Lord Auckland contributed one thousand rupees each for the new theatre. The new Sans Souci opened on 8 March 1841 with a production of Sheridan Knowles's The Wife (Dasgupta, 1988: 269). The theatre's fortunes dwindled when in 1843, during a performance of The Merchant of Venice, Mrs. Leach's costume caught fire. She was fatally burnt and succumbed to her injuries in a few days. Financial troubles forced the theatre to shut down in 1849. However, a year before its closure Sans Souci witnessed a performance of Othello which is significant in the annals of Indian theatre because a 'native' played the lead role for the first time in an otherwise all-British cast. The play was directed by James Barry and had Mrs. Leach's daughter playing Desdemona, with Basihnav Charan 'Addy', a Bengali, as Othello. It may be argued that the Indian actor was probably not cast for his histrionic talents but his colour which made him suitable for the role. This seems to be endorsed by a report in an English newspaper which called him a "real unpainted nigger Othello" which set "the whole world of Calcutta agog" (Raha, 1978: 13). The novelty of a 'native' playing Othello was advertised in the Calcutta Star thus:

On Thursday Evening, August $10^{\text {th }}, 1848$, will be acted Shakespeare's Tragedy of 'Othello'. Othello ... the Moor of Venice ... By a Native Gentleman ... (Mitra cited in Chatterjee, 2007: 59). 
While the Bengal Harkaru's review of August 19 praised Addy's confidence and pronunciation of English as an achievement for a native, the review in The Englishman criticized Addy's speech and pronunciation, but lauded him for attempting the role:

In the delivery, however, the effects of imperfect pronunciation were but too manifest. This was to be expected, but not to the extent it occurred. Scarcely a line was intelligible, and this did not arise from the low tone of voice; Othello spoke quite loud enough, but he 'mouthed' too much. Had he spoken in his natural tone, he would have succeeded far better. His action was remarkably good in some parts, and once or twice when he delivered himself in a modulated tone, we were much pleased with the effect produced. Taking it as a whole, we consider the performance wonderful for a Native. It reflects great credit on his industry and performance. (Mitra cited in Chatterjee, 2007: 64)

Singh, following Bhabha's concept of mimicry, sees Addy's entry into the colonial world as disrupting the simple colonizer-colonised binary whereby the Bengali actor by putting on the "white mask" also "enacted his difference from the white world, both in fictional Venice and in colonial Calcutta" (1989: 446). She elaborates that instead of being appropriated by "the colonial sahib's play-text, the Indian actor revealed the ambivalence of its cultural authority through a native strategy perhaps best described by Homi Bhaha as "camouflage, mimicry, black skin/white masks", (446).

Thus it is obvious that prior to 1831 , when the first Bengali theatre named The Hindu Theatre was established, there was ample theatrical activity on the part of the British. This played an important role towards establishing modern Indian theatre. Whether the Indian elite had access to these theatres prior to 1813 is not easy to ascertain, but in all probability, the audiences were exclusively British. Raha notes that even the ushers and doorkeepers of such theatres were "Englishmen" (1978: 13). Even if the Indian elite did not have direct access to these theatres, they may have been influenced by extensive coverage of the performances in these theatres by various newspapers. P. Guha-Thakurta notes that the Calcutta Gazette, the Bengal Hurkara, the Bengal Courier and the Asiatic Journal regularly published notices and reviews of the performances held at the Chowringhee Theatre (1930: 42). The Calcutta Gazette, one of the earliest English language newspapers in India, founded in 1784, gave a description of Mrs. Emma Bristow's residential theatre at Chowringhee in its issue of 7 May 1789: "It was not merely an apartment in a house temporarily fitted up for a single representation, but a distinct edifice completely furnished with every usual convenience and decorated with every ornament customary in familiar places of exhibition - in short, a perfect theatre differing only from a public one in its dimension" (cited in Mukherjee, 1982: 3). The Calcutta Gazette dated 31 August 1815 wrote about a performance of Richard III held on 25 August 1815: "We have not known there of any representation for some time past with more success" (cited in Guha-Thakurta, 1930: 42).

Gradually, these theatres opened their doors to the Indian elite, which furthered the cause of establishing theatres by Indians. The reason for this selective inclusion of the 'natives' into English society was the realization on the part of the British that it would 
be difficult to exercise control over the 'natives' if they exercised the policy of segregation. Having understood the need to co-opt the native elite as a "conduit of Western thought and ideas", the British employed the strategy of, what Homi Bhabha calls, "mimicry" whereby the 'native' elite was encouraged to 'mimic' English culture, values, habits and assumptions (Viswanathan, 1987: 10; Also see Bhabha 1994). This inclusion of the Indian elite can be seen as a strategic move to expose them to Western culture and values and to create "a class of persons Indian in blood and colour, but English in tastes, opinions, in morals, and in intellect" (Macaulay, 1972: 249). Theatre was a vital instrument that could provide the elite Indians with access to English culture. The first prominent member of the Bengali aristocracy to enter the English theatre circuit was Dwarkanath Tagore, who was also one of the founding members of the Chowringhee Theatre along with D.L. Richardson, Dr. H.N. Wilson and Henry Meredith Parker. Subsequently, the English colonial authorities encouraged the 'natives' to establish their own theatres. The strong urge to have theatres of their own came not only from the English-educated Indian elite but also from the orthodox nationalists. One such project of 'imitation' can be found in the following editorial of Samachar Chandrika, a nineteenth-century orthodox Hindu newspaper in Bengali, as quoted in Asiatic Journal:

In the extensive city public institutions of various kinds and moral descriptions have lately sprung up for the improvement and gratification of its inhabitants; but their amusement has not yet been consulted and they have not, like the English community, any place of public entertainment. ... It is therefore very desirable that men of wealth and rank should associate and establish a theatre on the principle of shares, as the English gentlemen have done, and retaining qualified persons on fixed salaries, exhibit a performance of song and poetry once a month conformably to the written natakas or plays ... such a plan will promote the pleasure of all classes of society (August 1829).

This shows that the need to imitate the colonial master was, at least on the part of the nationalists, a sort of retort to stress that they were in no way inferior to them. The flip side to this, as Sudipto Chatterjee states, was the Bengali quest for a distinct cultural identity that would "set them on a par with their European overlords" (1995: 20). A committee was formed to establish a theatre based on the English model. The members were Prasanna Kumar Tagore, Srikrishna Sinha, Krishna Chandra Dutt, Ganganarayan Sen, Madhab Chandra Mullick, Tarakchand Chakravorty and Hara Chandra Ghosh. As a result, the Hindu Theatre opened on 28 December 1831 in the garden-house of Prasanna Kumar Tagore. Although this theatre was set up for a Bengali audience and was established in a predominantly Bengali quarter, the plays performed were either in English or English translations of Sanskrit plays. The theatre was inaugurated with the performances of Act V of Shakespeare's Julius Caesar and Act I of Bhavbhuti's Uttarramcharit translated into English by H. H. Wilson. The Calcutta Courier reported, "Babu Prasanna Kumar Tagore has fitted up a neat little stage in his house in Narkeldangah where some young Hindoo gentlemen admirably schooled in the Histrionic art exercise their talents for the amusement of their native and European 
friends who are admitted by invitation" (4 April 1832; italics mine). The theatre was not really a public one as it catered to an exclusive audience. It closed down after staging another performance in English.

\section{2. 'Imitating' English Shakespeare on the Calcutta stage}

The interest of the Indian elite in Western culture and theatre coincided with the British colonial policy of institutionalizing English education in India, which played an important role in promoting Shakespeare and contributed to the growth of modern Indian theatre. The aim of imparting English education in India was from the very beginning a political strategy to consolidate British control over the subcontinent. In the words of Macaulay, English education was necessary to "form a class who may be interpreters between us and the millions whom we govern" (1972: 249).

The middle-class Indian accepting the colonial master as 'saviour' was more than willing to adopt western education. Indian social reformers like Ram Mohun Roy felt "fully justified in stating that two-thirds of the native population of Bengal would be exceedingly glad to see their children educated in English learning" (cited in Prakash, 2005: 58). This aim could not have been realized before establishing the Orient as uncivilized and justifying the 'civilizing mission' of the West. This involved creating stereotypes about the Orient and then defining the Occident against those stereotypes. This way of defining the Orient, argues Edward Said, is a corporate institution "dealing with it by making statements about it, authorizing views of it, describing it, by teaching it, settling it, ruling over it: in short, Orientalism as a Western style for dominating, restructuring, and having authority over the Orient" (1991: 3). As this knowledge about the Orient is created, the Occident could define itself against the Orient by making comparative evaluations and, thereby, emerge as the 'superior' and 'civilized' culture. We should bear in mind here that the knowledge created by the Orientalists is not objective but, as Said argues, "it is at once controlled, selected, organized and redistributed according to a certain number of procedures" (1980: 181). Once the Orient takes this construct to be true, it gives the Occident the authority required to rule over the former. As Gauri Viswanathan notes:

Through its government-supported research and scholarly investigations Orientalism had produced a vast body of knowledge about the native subjects that the Anglicists subsequently drew upon to mount their attack on the culture as a whole. (1989: 30)

Once the 'superiority' of the British was established, it turned to 'educate' the 'uncivilized' and 'morally depraved natives'. However, under the guise of education there were political and economic interests of the British. The educated Indian would provide the British with cheap labour in the form of baboos for administrative jobs. The larger function that this would serve is well stated by Charles Trevelyan, a civil servant and brother-in-law of Macaulay, who noted, "[T]hey will then cease to desire and aim at 
independence on the old Indian footing ... and a long continuance of our present connection with India will even be assured to us" (1838: 93). There was, however, a clash as to what should form the subject of study. The missionaries wanted to impart western education to the 'natives' through the religious morals and values of Christianity, as was the case in England where the Church exerted influence on educational institutions. However, the colonial authority feared violent reactions from the 'natives' - especially the educated ones - if such a religious education were to be imposed upon them. A more secular education was favoured for the 'moral upliftment' of the 'natives'. English language and literature were the best possible alternatives for the British (although it had still not been established as a discipline in Britain itself) rather than religious studies or military control. Thus, literature was appropriated to inculcate among the 'natives' European values, beliefs, assumptions and tastes. An ideological and humanistic function was assigned to language and literature, which was, as Viswanathan argues, "vital in the process of sociopolitical control" (1987: 2). The desired role that literature was to play was clearly manifested by Horace Wilson, who emphasized the need to "initiate them [Indians] into our literature, particularly at an early age, and get them to adopt feelings and sentiments from our standard writers, can we make an impression on them, and effect any considerable alteration in their feelings and notions" (cited in Viswanathan, 1989: 48). There were, however, two thoughts as to how the 'natives' should be educated. While the Orientalists wanted to impart education in the European knowledge system through native languages along with indigenous forms of knowledge, the Anglicists favoured imparting European knowledge in the medium of the English language. The Anglicists finally won this debate, and consequently, English education and the English language as the medium were institutionalized in 1835.

Whether it was introducing the 'natives' to English knowledge and language or providing them with access to English theatres, both were, in effect, manifestations of Gramscian 'hegemony' whereby "Domination is [thus] exerted not by force, nor even necessarily by active persuasion, but by a more subtle and inclusive power over the economy, and over state apparatuses such as education and the media, by which the ruling class's interest is presented as the common interest and thus comes to be taken for granted" (Ashcroft et al., 2009: 116; see Gramsci, 1991). Ania Loomba argues that English education offered "a programme of building a new man who would feel himself to be a citizen of the world while the very face of the world was being constructed in the mirror of the dominant culture of the West" (1989: 21). In this way, English education proved to be an effective tool of domination for the British as the Indian elite welcomed the advent of English education as a window to the new world which was 'rational' and culturally and morally 'superior'. Shakespeare formed the core of the curriculum of English education imposed by the British. Even the missionaries had earlier resisted the British policy of secular education in favour of a religious one found in Shakespeare, along with Goldsmith, a champion of their agenda. Hence, from the beginning Shakespeare was made to bear the burden of the civilizing mission of the British. It was necessary therefore to valorize Shakespeare and represent his plays as 
'universal', 'timeless' and 'transcendental'. This proved quite successful as the native elite took to Shakespeare and made him synonymous with 'universal humanism'.

In addition to the formal introduction of Shakespeare, there were other reasons that helped strengthen Shakespeare's position. For instance, Shakespeare was taught by British teachers like Henry Derozio and D. L. Richardson who created among their students an unfading admiration for the dramatist. They taught students not only to recite lines from Shakespeare's plays, but to enact them as well. Richardson advised his students to watch Shakespeare productions (of course, the English ones staged by British actors). Macaulay noted of Richardson: "I may forget everything else about India, but your reading of Shakespeare never" (cited in Presidency College, Centenary Volume, 1956: 4). The 1853 Act which introduced a competitive examination for the civil service included English language and literature as optional subjects which included Shakespeare's plays. Also, the travelling companies that frequently visited India performed Shakespeare's plays and helped to popularize them among educated Indians. Soon it became the rage among educated Bengalis to stage Shakespeare. As late as 1926, the English professor C.J. Sisson observed this fad for performing Shakespeare among Indian students who "busy[ied] themselves almost exclusively with Shakespeare in English" (1926: 15).

Early nineteenth-century Shakespearean productions in Calcutta, which were mostly student productions, seem to have been 'faithful' to English culture and language. Emily Eden, who had spent some years in India with her brother in the early nineteenth century, gave one such account of Calcutta College in her letters to her sister:

Yesterday we had an examination at Government House of the Hindu College, and the great banqueting-hall was completely filled with natives of the higher class. Some of the boys in their gorgeous dresses looked very well, reciting and acting scenes from Shakespeare. It is one of the prettiest sights I have seen in Calcutta. (1919: 265)

Most notable were the performances and recitations by the students of Hindu College and Sanskrit College. In 1837, the students performed The Merchant of Venice at the Government White House under the supervision of Dr. Wilson. It was staged twice by the David Hare Academy students in 1853. The Bengal Hurkara of 28 February 1853 observes:

Mr. Clinger, Headmaster of the English Department of the Calcutta Madrassa gave instruction on Shakespeare's dramatic plays to the alumni of the David Hare Academy and succeeded in training some boys to the competent performance of the plays taught [to] them and accordingly the play took place on two nights in the hall of the Institution. The part of Shylock was pronounced the best and the Merchant of Venice etc. was rather defective which it was hoped, diligence and performance would perfect in time (my italics).

Hemendra Nath Dasgupta notes that the play was attended by some 600-700 Indians and Englishmen who were quite pleased with the performance (1988: 299). Other Shakespeare enthusiasts were to be found in the Oriental Seminary. In 1853, the 
students and ex-students of the Oriental Seminary "raised a subscription of Rs.800 among themselves and with that the stage was built and dresses purchased" (Bengal Hurkara, 7 April 1853). The new theatre, which was called the Oriental Theatre, was situated on the school premises. The theatre was established mainly for staging Shakespeare plays and opened on 26 September 1853 with a production of Othello, with a repeat performance on 5 October 1853. The production received rave reviews from newspapers. Bengal Hurkara (28 Sep. 1853) appreciated the production for helping to 'improve' the 'native' intellect:

The performers were, all of them, young men ... and the character which we feared would be the worst represented, was the best represented - Iago by Babu Prianath Dey [Dutt] was acted with an evident knowledge of the character ... the mode in which they acquitted themselves must have given much satisfaction to every member of the audience who cares for the intellectual improvement of his native fellow-citizens (my italics).

Another performance at the Oriental Theatre was advertised in The Citizen (2 March 1854). The Morning Chronicle of the same day appealed to:

[T]hose who are desirous of seeing how young native gentlemen can wear the buskin, should attend the Oriental Theatre this evening and we promise them that they will come away with a higher impression of native tragic talent than that which they may possibly, at present, be improved.

The productions of the Oriental Theatre are significant because the performances were open to the public (anyone who could afford to buy a ticket to watch them) unlike the private theatres of Calcutta. But the Oriental Theatre had a short life and the last production was that of 1 Henry IV on 15 February 1855.

Apart from student productions, there were other productions held in private and public theatres in Calcutta. Pyari (Parry) Mohan Bose's Jorsanko Natyasala staged a much-acclaimed performance of Julius Caesar in English on 3 May 1854. Sambad Pravakar of 3 May 1854 showered praises on the production and compared it with the Oriental Theatre:

Pyari Babu's house was illumined and decorated in the nicest way. The audience numbered around 400, and would have been more but for rain and storm. Babu Mohendra Nath Bose acted in the role of Caesar, Kistoodhan Dutt of Brutus and Jadu Nath Chatterjee of Cassius and the artists were thus all of culture. Even the performance by the amateurs of the Oriental Theatre stood inferior in comparison, and they were astonished at the excellent way the performance of such a play was rendered.

However, The Hindu Patriot (11 May 1854) was quite critical of the production and condemned it for bastardizing the Bard:

We ourselves are the most steadfast admirers of the Drama. Nothing will give us greater pleasure than to behold Shakespeare springing into new life under the histrionic talent of 
our educated countrymen, but we cannot calmly look on while the old gentleman is being murdered and mangled.

From the above discussion it is clear that early Bengali theatre and its Shakespearean productions in the 1850 s were driven by a desire to 'imitate' the Western canons of drama and theatre. A change occurred in the post-1850s when the Bengali audience craved for Bengali plays. Newspapers started voicing the need to stage Bengali plays in Bengali theatres. The same review of The Hindu Patriot mentioned above further advised "the Joranskowallahs to take in hand a couple of good Bengallee plays and [we will] promise them success." In the same vein, the review of the Oriental Theatre's Henry IV lamented the lack of public response and advised the staging of Bengali plays (The Hindu Patriot, 21 February 1855). It was probably due to this reason that there was a decline in the number of Shakespearean productions from 1857 onwards. Bengali drama was on the rise. The first original Bengali play to be written was Ram Narayan Tarkaratna's Kulin Kulasarvasa (All About a Kulin Clan, 1854), which focuses on the evils of polygamy. The next 20 years saw the emergence of Bengali social drama when plays like Tarkaratna's Kulin Kulasarvasa and Naba-Natak (The New Drama, 1867), Umesh Chandra Mitra's Bidhba Bibaha (Widow Marriage, 1856), Michael Madhusudan Dutt's Sarmistha (1859) and Dinabandhu Mitra's Nildarpan (The Indigo Planting Mirror, 1860) were staged. 1872 witnessed the establishment of the first Bengali public theatre - the National Theatre - though housed in a private residence. Soon, more public theatres were opened in Calcutta, like the Hindu National Theatre (1873), the Oriental Theatre (1873), the Bengal Theatre (1873), the Star Theatre (1883), the Minerva Theatre (1893), the Emerald Theatre (1887) and the Unique Theatre (1903). However, the emergence of professional theatres in Calcutta saw the decline of the newly born Bengali social drama. Perhaps a reason for this was the institution of the Dramatic Performances Control Act of 1876. Rustom Bharucha says that professional Bengali theatre of the time "was not equipped to deal with the rigors of censorship on a theatrical level" (1983: 23).

\section{3. 'Indigenizing' Shakespeare in post-1850s Bengali theatre}

Bengali theatre during the last quarter of the nineteenth century seemed to follow the footsteps of Bombay's Parsi theatre. It was around this time that Shakespeare's plays began to be staged again with vigour albeit with a difference. They were now performed in Bengali by professional Bengali theatres. The trend was to 'indigenize' his plays. Hemchandra Bandopadhyay, for instance, in his "Introduction" to the translation of Romeo and Juliet defends his 'indigenization' of the play in the following words:

I have tried to present the story of the play of Shakespeare and the essential features of the characters in a native mould to suit the taste of the readers of my country. I cannot say how successful I have been. But I believe that without adopting such a method no foreign play will ever find a place in Bengali literature, which will be denied nourishment and 
advancement. After a period of such exercises, faithful translations of foreign plays and poems will find acceptance in Bengali literature. But now, for some time to come, I believe, this method is indispensable. (cited in Das, 2005: 58)

The earliest Bengali production of Shakespeare on the public stage was probably The Comedy of Errors in 1873. Nothing much is known about the performance. The following year saw the productions of Kusum Kumari, an adaptation of Cymbeline by Chandrakali Ghosh, at the National Theatre and Rudrapal, an adaptation of Macbeth by Haralal, at the Great National Theatre. R. K. Yajnik notes that the adaptation was too literal to impress regular playgoers (1933: 176). Ray had merely changed the English names to Hindu ones. As Sarottama Majumdar observes, "contemporary accounts report an unruly and abusive audience who actually managed at one performance to have the play abandoned halfway through" (2005: 237). Girish Chandra Ghosh's Macbeth was staged on the opening night of the Minerva Theatre in 1893. The event was reported by the newspapers as an important milestone in the history of Bengali theatre. The advertisement in Amrita Bazar Patrika on 28 January 1893 appeared as follows:

\section{Opening Night/ The Minerva Theatre/ 6 Beadon Street Saturday, the $28^{\text {th }}$ January, 9 P. M./ Shakespeare in Bengal/ MACBETH \\ I have got the piece mounted by European Artists and dressed it under European supervision and "make up" by Mr. J. Pimm. G.C. Ghosh Manager}

The set was mounted by one Mr. Weelard. Ghosh himself played the part of Macbeth, with Teenkouri as Lady Macbeth. The production proved to be a boon for Teenkouri's career, as she left an impression on the minds of the audience. The Indian Nation of 20 February 1893 praised Teenkouri's histrionics and commented, "[I]t is impossible to say of a Shakespearean play that it has been acted to perfection, but we can say of this play that it was acted very well at the Minerva. The parts that were especially well done were those of Macbeth and Lady Macbeth, who had a Mrs. Siddons-like appearance." In spite of Ghosh's best efforts the production did not fare well with the audience. Ghosh considered Shakespeare as his model and "had wanted the average theatergoer to be acquainted with the Bard's plays and nursed the hope of producing a number of his tragedies" (Raha, 1978: 41). However, with the dismal failure of Macbeth, which Ghosh had translated himself, his dream was shattered. The failure of this production is significant as it throws light on the Bengali taste of the time. While it was well received by the elite Calcuttans and the Anglo-Indian newspapers, the masses rejected it. The Englishman (8 February 1893) commented:

The second performance of Macbeth was shown before a large audience including several European gentlemen. Babu Girish Chandra Ghosh, the manager, played the part of Macbeth and the play as a whole was well rendered. A Bengali Thane of Cawdor is a 
living suggestion of incongruity, but the reality is an astonishing reproduction of the standard convention of the English stage.

The Hindu Patriot published a lengthy review of the production and considered it "a new departure in the dramatic history of Bengal" (cited in Dasgupta, 1944: 116). Unfortunately, the play had to be withdrawn from the boards after ten productions. The reasons for the failure of the production at the box-office might have been many. However, an important one, which Ghosh himself admitted, was the lack of songs and dances. In a letter addressed to a friend of his, he wrote, "most go to see songs and dances, few for drama. The public are [sic.] too uneducated to appreciate Shakespeare" (cited in Raha, 1978: 41). However, there was more to it than that. Although Ghosh had translated the play from English to Bengali, he did not take away the 'Englishness' from the text. The stage was English, the costumes were English, the make-up was English, the locale was Scotland, in fact the whole context was unfamiliar to the masses. Ghosh had failed to notice that the Bengali desire of 'imitating' the Western canon of drama and theatre by the late nineteenth century had given way to more local aesthetics. The Bengali audiences at public theatres did not want a mere substitution of names or locales in Bengali, but wanted a genuine Bengali play steeped in Bengali culture.

This brings me to another production of Shakespeare by Amrendra Datta staged on 21 June 1897, which was a huge success with the audience. The production was Hariraj, an adaptation of Hamlet by Nagendra Nath Chaudhuri for the Classic Theatre (1897-1906). The play ran for almost three years in Calcutta theatres. Amrendra Nath played Hariraj and Tarasundari acted as Aruna and in later productions as Srilekha. The play was a huge success, unlike Ghosh's Macbeth and many others that met the same fate. The Indian Mirror of 22 May 1900 praised Amrendranath extravagantly and wrote: "[W]e must confess that Babu Amrendranath, rightly called by the theater going public the Garrick of the Bengal stage, absolutely surpassed himself in it (Hariraj)." Amrendra Nath succeeded where Ghosh had failed —in 'indigenizing' Shakespeare. Raha notes Amrendra Nath's anticipation (1978: 76-7):

Amrendra Dutta foresaw that unless served as Bengali plays with names, locales, characters and situations metamorphosed into native equivalents - unless, that is, they were free adaptations - Shakespeare or, for that matter, any foreign playwright had little chance with the audience.

Another reason for the easy acceptance of Hariraj with the audience was probably that it did not acknowledge any relation with Shakespeare's Hamlet. Thus, for the Bengali masses Hariraj was a genuine Bengali play without any foreign air about it. Moreover, catering to the demands of the audience, Datta had incorporated a number of songs and dances. Shormishta Panja criticizes Bengali theatre historians for their failure to recognize Datta's contribution in bringing Bengali theatre closer to the masses like the "informal and interactive staging of Shakespeare's plays in Elizabethan England" (2008: 219). 
The period from 1912 to 1922 in Bengali theatre is generally regarded as the period of decline. With the death of Girish Ghosh in 1912, Bengali theatre started declining (see Mukherjee, 1982: 126-47). By 1912, the well-known dramatists and actors of the Bengali public stage had gone. The decade did not produce many plays of merit. It was probably due to the absence of worthy plays in Bengali that one finds some adaptations of Shakespeare during this period. However, these adaptations did not go down very well with the audiences. In 1913, Minerva Theatre staged Cleopatra, an adaptation of the original by Pramathanath Bhattacharya. The play had Tarasundari in the title role and Dani Babu as Antony. Amrita Bazar Patrika (5 Sep. 1913) advertised the play as having "new princely costumes and superb sceneries made in accordance with Western ideals, which with a very rich cast and loved songs and dances will certainly prove to be a unique display." Nothing much is known about the performance. However, a guess can be made by looking at the title, which suggests it is a 'faithful' translation of the original. It might not have met with much success, as there is hardly anything documented about the performance. Another performance of Shakespeare entitled Saudagar (The Merchant) featured Amrendranath again in 1915 at the Star Theatre. Saudagar was an adaptation of The Merchant of Venice by Bhupendranath Banerjee. The performance at the Star Theatre, unfortunately, turned out to be the last performance of Amrendranath. While performing the role of Kuliraka, Amrendranath vomited blood and later died. After Amrendranath's death, it was not until 1919 that a Shakespeare play was staged at the Star Theatre. The play was a Bengali translation of Othello by Devendranath Basu. The Bengalee (15 March 1919) praised Tarasundari, who played Desdemona: "We were assured by more than one critic that the acting of Desdemona approached perfection and the heroine had shown a remarkable power of adaptability which extorted unstinted praise from the audience." Dasgupta notes, "[T]he sales in the first night were good, but fell down from the second. None of the parts except that of Tarasundari was done to the spirit of the dramatist" (1944: 177). Othello failed for the same reason that Ghosh's Macbeth was unsuccessful: the translator had tried to be 'faithful' to the original, which did not match the expectations of the audience.

The 1920s witnessed a sea change in Bengali drama and theatre: "scenes and lighting arrangements, dress and properties, as well as in external arrangements and administrative matters", notes Mukherjee (1982: 152). As far as the content of the drama is concerned the focus once again shifted to the social and political instead of the mythological or supernatural, which later found manifestation in the Indian People's Theatre Association (IPTA). It was the availability of Bengali dramas that might have pushed Shakespeare to the margins, as there were not many Shakespeare plays being staged in Bengali theatre after the 1920s. Another reason might have been the growing fervour of nationalism, when a foreign playwright would need to struggle to find a place. It was only after Independence that Shakespeare was taken up for production by the Bengali stage with a new zeal, evident in Utpal Dutt's productions of Shakespeare's plays. The latest Shakespeare production in Calcutta is Suman Mukhopadhyaya's Raja Lear (King Lear, 2011) with Soumitra Chatterjee in the title role. 
From the above discussion it is clear then that there were two models of Shakespeare production in colonial Calcutta: one, the 'imitative' Shakespeare during the first half of the nineteenth century, produced largely by school and college students under the tutelage of their British teachers and by the educated elite of Calcutta at their private theatres, and the second, the 'indigenized' Shakespeare in the post-1850s, produced by professional Bengali theatre companies. The 'indigenized' Shakespeare also proves helpful in understanding the complex reception of Shakespeare in India in a more nuanced way. Unlike the lop-sided view put forth by some post-colonial scholars that Shakespeare was passively received in colonial societies like India, the 'indigenized' Shakespeare on the Calcutta stage proves that it was governed by its own aesthetics. There is no doubt that Shakespeare was introduced in the Indian curriculum to serve the British colonists' agenda, but the 'indigenized' Shakespeare on the Calcutta stage refused to be overwhelmed by the master's text and in fact appropriated the text itself.

\section{References}

Ashcroft, Bill, Gareth Griffiths and Helen Tiffin (2009): Post-Colonial Studies: The Key Concepts. London: Routledge.

Bhabha, H.K. (1994): The Location of Culture. London: Routledge.

Bharucha, Rustom (1983): Rehearsals of Revolution: The Political Theater of Bengal: Seagull.

Bhatia, Nandi (2004): Acts of Bengal. Calcutta Authority/Acts of Resistance. New Delhi: OUP.

Chatterjee, Sudipto (1995): "Mise-en-(Colonial-) Scene: The Theatre of the Bengal Renaissance." In Imperialism and Theatre: Essays on World Theatre, Drama, and Performance 1795-1995. J. Ellen Gainor, ed. London: Routledge, 19-37.

----- (2007): The Colonial Staged: Theatre in Colonial Calcutta. Calcutta: Seagull.

Clive, J. and T. Pinney Macaulay, eds. (1972): Thomas Babington Macaulay: Selected Writings. Chicago: University of Chicago Press, 237-251.

Das, S. K. (2005): “Shakespeare in Indian Languages." In India's Shakespeare: Translation, Interpretation, and Performance. Poonam Trivedi and Dennis Bartholomeusz, eds. Delhi: Pearson Longman, 42-65.

Dasgupta, Hemendranath (1944): The Indian Stage, Vol. I-IV. Calcutta: K. V. Apparow.

----- (1988): The Indian Theatre. Delhi: Gian Publishing House.

Eden, Emily (1919): "Miss Eden to Mrs. Lister", Letter from Barrackpore. March 24,1836. In Miss Eden's Letters. Violet Dickinson, ed. London: Macmillan.

Guha-Thakurta, P. (1930): The Bengali Drama: Its Origin and Development. London: Kegan Paul \& Co. Ltd.

Loomba, Ania (1989): Gender, Race, Renaissance Drama. Manchester: Manchester University Press.

Majumdar, Sarottama (2005): “That Sublime 'Old Gentleman': Shakespeare's Plays in Calcutta, 1775-1930." In Poonam Trivedi and Dennis Bartholomeusz, eds. India's Shakespeare: Translation, Interpretation, and Performance. Delhi: Pearson Longman, 232239. 
Mukherjee, Sushil Kumar (1982): The Story of the Calcutta Theatres: 1753-1980. Calcutta and New Delhi: K. P. Bagchi \& Company.

Panja, Shormishtha (2008): "Shakespeare on the Indian Stage: Resistance, Recalcitrance, Recuperation." In Robert Henke and Eric Nicholsan, eds. Transnational Exchange in Early Modern Theater. Hampshire: Ashgate, 215-224.

Presidency College, Calcutta, Centenary Volume. Calcutta: W.B. G. Press, 1956.

Raha, Kironmoy (1978): Bengali Theatre. New Delhi: National Book Trust.

Said, Edward (1980): "The Text, the World, the Critic." In Josue V. Harari, ed. Textual Strategies: Perspectives in Post-Structuralist Criticism. London: Metheun \& Co., 161-188.

----- (1991): Orientalism: Western Conceptions of the Orient. London: Penguin.

Singh, Jyotsna (1989): "Different Shakespeares: The Bard in Colonial/Postcolonial India." Theatre Journal, 41. 4: 445-58.

- (1996): Colonial Narratives/Cultural Dialogues: "Discoveries" of India in the Language of Colonialism. London: Routledge.

Sisson, C. J. (1926): Shakespeare in India: Popular Adaptations on the Bombay Stage. London: The Shakespearean Association.

Trevelyan, Charles E. (1838): On the Education of the People of India. London: Orient Longman.

Trivedi, Poonam (2005): "Introduction." In Poonam Trivedi and Dennis Bartholomeusz, eds. India's Shakespeare: Translation, Interpretation, and Performance.. New Delhi: Pearson Longman, 13-41.

Viswanathan, Gauri (1987): "The Beginnings of English Literary Studies in India." Oxford Literary Review 9: 2-26.

----- (1989): Masks of Conquest: Literary Study and British Rule in India. London: Faber and Faber.

Yajnik, R.K. (1933): The Indian Theatre: Its Origins and its Later Developments Under European Influence. London: George Allen \& Unwin Ltd.

Newspapers, Bulletins and Gazettes:

Amrita Bazar Patrika, 28 Jan. 1893.

Amrita Bazar Patrika, 5 Sep. 1913.

Bengal Hurkara and India Gazette, 28 Feb. 1853.

Bengal Hurkara, 7 April 1853.

Bengal Hurkara, 28 Sep. 1853.

The Bengalee, 15 March 1919.

Calcutta Courier, 4 April 1832.

Calcutta Gazette, 28 Feb. 1788.

The Citizen, 2 March 1854.

The Englishman, 8 Feb. 1893.

Hindu Patriot, 21 Feb. 1855.

Hindu Patriot, 11 May 1854.

Indian Mirror 22 May 1900.

Indian Nation, 20 Feb. 1893.

Morning Chronicle, 2 March 1854.

Sambad Pravakar, 3 May, 1854.

Selections from Calcutta Gazettes. 